\title{
Instilling Trust Among China's Online Customers On E-Commerce Platform
}

\author{
Siti Intan Nurdiana Wong Abdullah ${ }^{1 *}$ Phuah Kit Teng ${ }^{2}$ \\ Bernard Lim Jit Heng ${ }^{3}$ Liu Ying ${ }^{1}$
}

\begin{abstract}
${ }^{1}$ Faculty of Business, Communication and Law, INTI International University, Persiaran Perdana BBN, Putra Nilai, 71800 Nilai, Negeri Sembilan, Malaysia

${ }^{2}$ Department of Marketing, Faculty of Accountancy, Finance and Business, Tunku Abdul Rahman University College, Kampus Utama, Jalan Genting Kelang, 53300 Kuala Lumpur, Malaysia

${ }^{3}$ Center of University Hertfordshire Programmes, INTI International College Subang, 47500 Subang Jaya, Selangor. *Corresponding author. Email: sitiintan.abdullah@newinti.edu.my
\end{abstract}

\begin{abstract}
In recent years, business-to-consumers (B2C) e-commerce platforms has developed rapidly in China triggered numerous attentions from the government, enterprises, consumers and even the academician. Due to the unpredictability nature of the e-commerce environment, trust has become significant factor in determining one's competitive advantage. However, existing customer's attitude and safety awareness are not optimistic towards the online shopping and e-commerce enterprises. Such lack of trust has caused the buyers and sellers to experience communication breakdown. Hence, it is very meaningful to investigate the factors which can enhance customer's trust on B2C websites. In this study, a quantitative approach was applied to examine the relationship between the influencing factors and trust among 384 respondents from China. The results indicated that all the factors were positively correlated to consumer trust and product quality has the highest influence on customer trust. This is followed by website quality, company brand reputation, after-sales service and the customer attitude towards risk in the $\mathrm{B} 2 \mathrm{C}$ e-commerce in China. Thus, it is expected that the $\mathrm{B} 2 \mathrm{C}$ e-commerce will continuously improve their product and website quality in order to remain competitive in the market.
\end{abstract}

\section{Keywords: Attitude, consumer trust, e-commerce, quality, reputation}

\section{INTRODUCTION}

After more than ten years of development, e-commerce has become China's important emerging industry due to its growing potential as commercial operandi. Through ecommerce, people can buy goods and make reservation through the network without the need to leave home. This provided the great convenience to people's life. Besides, people's daily consumption changes constantly with the rapid development of electronic commerce, evolving of traditional retailing into electronic business channels positively, and the advancement of retail mode make an optimistic breakthrough in retail study. In 2015, China's online shopping market size is around 3.8 trillion yuan and this figure increased by $36.2 \%$ compared with the previous year [1]. In terms of the structure of online shopping market, B2C accounted for $51.9 \%$, annual accounted is more than Consumer-to-consumer $(\mathrm{C} 2 \mathrm{C})$ for the first time. China's total retail sales of social customer goods reached 30.1 trillion yuan in 2015 , the network shopping is $12.6 \%$ of total retail sales of social customer goods, compared with 2014 increased by $2 \%$ [1]. As the online shopping gradually evolving into Internet consumption, many enterprises which previously focus on offline sales way accepted online retail sales method. This has increasingly become an indispensable change for business retail model. With perfect service and regular supply channels, B2C developed rapidly over the years, while the growth rate of $\mathrm{C} 2 \mathrm{C}$ showed a downward trend year by year.

Despite the rapid development of e-commerce, the constraints on industry development are gradually visible. For example, electronic commerce law, logistics system, the credit system and the regulation system required improvement. This created lack of trust on the e-commerce and hindered the progress. According to China Internet Security Report [2], China's Internet users still encounter malware, phishing site, harassing phone calls, spam message, network fraud, concern with the communication effectiveness and network information fraud in 2015. At present, trust factor remains the biggest bottleneck for the development of e-commerce in China. Furthermore, the online shopping-related complaints accounted for $25 \%$ of the total issues in 2016 [3]. The main network problems consist of issues like slow logistics, poor after-sales service, poor product quality, incompatible products, online fraud and so on are encountered by online consumers. The present study aimed to address the importance of establishing trust with online enterprises for of online shopping development. 


\section{LITERATURE REVIEW}

\subsection{Underpinning Concept on Trust and Related Variables}

Barber [4] defined trust as having confidence on the natural and moral social order through social interaction. Some scholars put forward the macro level of trust phenomenon that is different from the "personal trust", such as the "system trust" [5], "institution-based trust" [6]. From psychological perspective, trust is a subjective assessment of an entity towards another entity of impending behavior before monitoring the opposite behavior [7]. Lewis [8] regards trust as the outcome of relationships, and emotional associations of relationship that determined the interpersonal attitude.

Corritore [9] concluded the definition for online trust after summarizing the research about the trust in the traditional field, namely, the persons' attitude to their expectations in the risk of virtual environment. Aslam et al., [10] points out that customer trust tendency, evaluation on sellers, payment security, comparing the network product price and the traditional transaction price, comparing network product quality and the traditional trading product quality, the thirdparty assessment, online product delivery time, customers' level of education, the time of contact the network and online shopping experience had a significant impact on online shopping. Koufaris and Hampton-Sosa [11] stated that the network shopping trust from the buyers and the sellers forms the mutual trust relationship in the network transactions, mainly include the customers trust degree to the website and online business's ability, goodwill and integrity.

Familiarities refer to when an innovative technology or a new product is introduced in the market, Internet users learn about it, decide whether to buy it and whether to repeat purchasing it in the future. Such familiarity will assist consumers to decide whether adopt it or not. Hoffman, Novak and Peralta [12] stated that familiarity of websites and security will influence customers trust in e-commerce. Besides, Mcknight, Choudhury and Kacmar [13] devised an integrated model to examine perceived enjoyment, perceived ease-of-use and perceived usefulness in affecting customers' purchase intention in the online shopping. Ruyter, Wetzels and Kleijnen [14] studied the effect of ecommerce site on influencing the online trust of online shoppers using the online trading platform. Kima and Prabhakar [15] examined the influence of website usability on customer trust. Lee and Turban [16] proved that the website's aesthetic and transaction security can impact customer purchase intention. On the other hand, cybercrimes and hackers might influence the trust by misappropriating the familiarity. This is because hackers may access personal financial information using the confidential information exchange between vendors and clients over the Internet. As such, security had become a main factor influencing the purchase of products on the Web.
Zhang and Zhang [18] think the trust is the same regardless of e-commerce and traditional because the biggest difference between e-commerce and traditional is the different trade or communication medium. Yu [19] argues that online trust relies on the seller's ability, honesty, kindness and predictability of behavior intention. Wang and $\mathrm{Xia}$ [20] stated that customer trust in the network shopping depends on friendliness and trustworthiness of the seller. Zhang and Mao [21] mentioned that the influencing factors on acceptance of online transactions consist of these two aspects:

1. Technology - contains the safety of network, protection on the privacy of personal information, good navigation system and convenience of online payment.

2. Buyers / Customers - mainly concern on product quality, after-sales service, the online shop reputation, logistics distribution system, customer preference for trust, personal consumption psychology, presence of online shopping experience, friends or a third authority party's recommendation.

According to Cheung and Lee [22], the website quality, brand awareness, brand image and trust tendency influence on customer trust.

\subsection{Conceptual Framework}

Based on the above past studies, the conceptual framework is presented below:

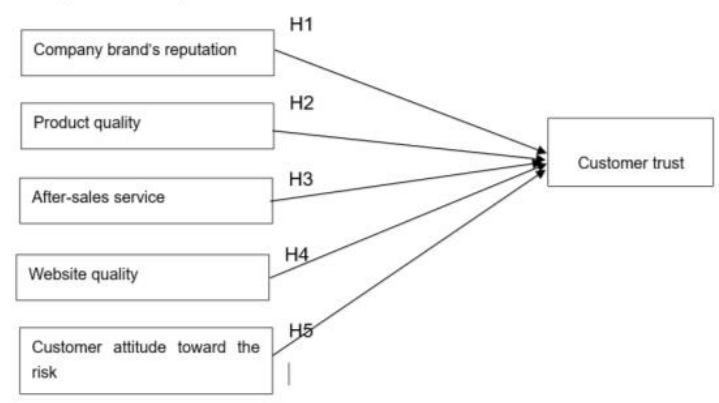

Brand reputation is an important factor as it shows how a brand is viewed by their customer. It is able to increase customer's loyalty and build confidence among the customers. McKnight, Choudhury and Kacmar [13] stated that there is a positive relationship between the reputation and trust. They found that reputation for customers trust belief and trust intention have a significant positive effect. Therefore, this study hypothesized that there is a relationship between the company brand's reputation and customer trust.

H1: Company brand's reputation will have a positive relationship with customer trust.

Product qualities incorporate the attribute and benefits that have the capacity to satisfy consumer needs and wants. Tan and Sutherland [23] reasoned that customer buying goods on the Internet relied on the picture or list of foods provided by suppliers. If supplier deliberately displayed distortion or provide incomplete information of goods, customer will be 
dissatisfied and will look for other offers. The diversity of products offers and the difficulty to identify quality products on the Internet may also affect customer trust in the e-commerce. If the product exhibited on the internet is detailed and informative, the clearer the customer perception of the goods and this will help increase the customer trust when shopping online [21].

$\mathrm{H} 2$ : Products quality will have a positive relationship with customer trust.

In the conventional trade mechanism, enterprise (including the manufacturers and sellers) can provide good and thoughtful after-sales service for customer who have bought the product or services from the business, which is the key to the success of enterprises [24]. From the existing literature, previous researchers have a consistent conclusion for enterprise service quality and customer trust relationship has significant effect on customers [25].

H3: After-sales service will have a positive relationship with customer trusts.

The quality of the website offers reliable and useful information, user friendly and easy to access, have a good design and visual appearance which are able to meet the consumers' needs and expectation. Kim, Xu and Koh [26] summarized that people perceived website quality according to the acceptance of new technology and innovations, which will affect the customer trust. This is aligned with the study by Tsai et al. [27] as the quality of the website is perceived to have impact on customer trust especially among online customer. Benamati and Serva [28] reasoned that such occurrence is due to the capability of virtual technology in securing customer belief and confidence. Salo and Karjaluoto [29] also stated that the website quality has an influence on customer trust in the research.

H4: Website quality will have a positive relationship with customer trust.

Attitude is an individual favorable or unfavorable feeling or action towards a person, product, services or a situation. Past study postulated that customer attitude toward risk can significantly affect the customer trust [30]. According to Hoffman [12], customers perceived risk on online shopping is one of the biggest factors for customer building trust. H5: Customer attitude toward the risk will have a positive relationship with customer trust.

\section{METHODS}

This quantitative research utilized deductive research with defined theoretical framework and established hypotheses in the literatures [31]. After determining the size of the population, non-probability sampling method is employed.
Due to the limitation of random sampling such as difficult to achieve the targeted objective and limitation of money, time and workforce [31], this research will apply the snowball sampling. The advantages of snowball sampling are its' ability to identify hidden population and finding a specific population. This sampling method does not incur complex planning and the staffing requirement as compare to other methods [31]. The sample respondents are drawn from Chinese online B2C users currently residing in China. The required sample size for this study is 384 based on Krejcie \& Morgan [32]. Respondents who have participated in this study are online consumers. The respondent's age mainly concentrated from the age of 18 years old to 40 years old because respondents from this age group are tech-savvy and are competent online. A self-administered online survey is used to test the influencing factors on customer trust in $\mathrm{B} 2 \mathrm{C}$ e-commerce and the questionnaire website link is sent to the respondents via QQ and Wechat.

As this research focus on Mainland China online shopping users and these respondents are all Chinese customers, it is more appropriate to use Chinese language. Hence, the questionnaires contained both English and Chinese language to facilitate the understanding of the respondents. The dual language questionnaire was verified by three respective individuals who consist of two other academic staff from a Malaysian university and one other language expert from China to ensure that the language expressed the similar meaning and avoid misinterpretation. To ensure the validity of the survey, a certified language instructor has been asked to check the questionnaire before it is distributed. Section A consists of 20 questions on the variables and Section B consists of 6 demographic questions. For the measurement of the variables, a fivepoint Likert Scale ranging from "1 - Strongly Disagree" to "5 - Strongly Agree" were used. The questions were adapted from the study of McKnight [13] and Krishnan and Aron [33].

Reliability test is used to measure the consistency of data [34]. A pilot test was conducted from 30 participants' responses. Table 1 shows the statistical result of reliability analysis of this research's pilot test. To summarize, all variables' Cronbach's Alpha value are above 0.7 except for the variable of Website Quality. The table also presents the results of Cronbach's Alpha value if a certain item is removed. So, the Cronbach's Alpha value if item deleted of Q14 is 0.706 which will increase above 0.70 , based on the criterion of Cronbach's Alpha [35]. This indicates that Q14 - 'I buy goods from this online company because the company's website running stable' has lower internal 
Table 1 Reliability test of pilot test

\begin{tabular}{|c|c|c|c|c|c|c|c|}
\hline Variable & Number of items & $\begin{array}{l}\text { Cronb } \\
\text { ach's } \\
\text { Alpha }\end{array}$ & $\begin{array}{l}\text { If Item } \\
\text { Deleted }\end{array}$ & $\begin{array}{l}\text { Variabl } \\
\text { e }\end{array}$ & Number of items & $\begin{array}{l}\text { Cronb } \\
\text { ach's } \\
\text { Alpha }\end{array}$ & $\begin{array}{l}\text { If Item } \\
\text { Deleted }\end{array}$ \\
\hline $\begin{array}{l}\text { Company } \\
\text { brand's } \\
\text { reputation }\end{array}$ & $\begin{array}{l}3 \\
\text { Q5-I prefer famous } \\
\text { online brands } \\
\text { Q6 I buy from } \\
\text { reputable sellers only } \\
\text { Q7 I prefer sellers } \\
\text { with positive } \\
\text { evaluation }\end{array}$ & 0.764 & $\begin{array}{l}0.707 \\
0.698 \\
0.635\end{array}$ & $\begin{array}{l}\text { Website } \\
\text { quality }\end{array}$ & $\begin{array}{l}4 \\
\text { Q14-I shop online } \\
\text { because its easy to } \\
\text { get the information } \\
\text { Q15-I prefer online } \\
\text { shopping as it's easy } \\
\text { to use the website } \\
\text { Q16 I prefer online } \\
\text { shopping because } \\
\text { the website has clear } \\
\text { navigation } \\
\text { Q17 I prefer online } \\
\text { shopping because } \\
\text { the website is well- } \\
\text { designed }\end{array}$ & 0.676 & $\begin{array}{l}0.509 \\
0.584 \\
0.622\end{array}$ \\
\hline $\begin{array}{l}\text { Product } \\
\text { quality }\end{array}$ & $\begin{array}{l}3 \\
\text { Q8 Online products' } \\
\text { quality are the same } \\
\text { as the store } \\
\text { Q9 Online products' } \\
\text { quality fits its } \\
\text { description } \\
\text { Q10 Online products } \\
\text { perform reliably }\end{array}$ & 0.771 & $\begin{array}{l}0.460 \\
0.693\end{array}$ & $\begin{array}{l}\text { Attitude } \\
\text { towards } \\
\text { risk }\end{array}$ & $\begin{array}{l}3 \\
\text { Q18 I feel safe to } \\
\text { enter my credit/debit } \\
\text { card information } \\
\text { Q19 I don't mind } \\
\text { giving my personal } \\
\text { information online } \\
\text { Q20 The internet } \\
\text { security technology } \\
\text { is reliable }\end{array}$ & 0.707 & $\begin{array}{l}0.496 \\
0.695\end{array}$ \\
\hline $\begin{array}{l}\text { After sales } \\
\text { service }\end{array}$ & $\begin{array}{l}3 \\
\text { Q11 The after sales } \\
\text { services are excellent } \\
\text { Q12 I can exchange } \\
\text { products bought } \\
\text { online conveniently } \\
\text { Q13 The online seller } \\
\text { provides same level } \\
\text { of after sales service } \\
\text { as the store }\end{array}$ & 0.711 & $\begin{array}{l}0.656 \\
0.606 \\
0.601\end{array}$ & $\begin{array}{l}\text { Custom } \\
\text { er trust }\end{array}$ & $\begin{array}{l}4 \\
\text { Q1 I trust online } \\
\text { shopping } \\
\text { Q2 I enjoy buying } \\
\text { goods online } \\
\text { because I believe the } \\
\text { information } \\
\text { provided } \\
\text { Q3 The online seller } \\
\text { can be trusted } \\
\text { Q4 The online seller } \\
\text { is reliable }\end{array}$ & 0.836 & $\begin{array}{l}0.762 \\
0.811\end{array}$ \\
\hline
\end{tabular}

consistency compared with other items used to measure the Website Quality construct. Hence, for the final questionnaire, Q14 was deleted.

\section{FINDINGS AND DISCUSSIONS}

For this study, a total of 404 surveys were distributed and only 384 valid questionnaires were returned and used for further analysis. From the descriptive analysis (Table 2), more than half of the respondents (about 65.9\%) were female respondents while the remaining were male respondents (about 34.1\%.) Moreover, the majority of these participants were from the age group of 25-30 (about $62.2 \%), 18-25$ group and 31-40 group accounted for $19.8 \%$ and 14.8 respectively, the age of above 40 only accounted for $3.1 \%$. Nearly half of the respondents' highest education qualification is undergraduate, followed by the Master respondents and Junior college respondents with $21.9 \%$. In addition, the majority of respondents' occupation is company employee with $32.6 \%$, followed by students, liberal professions and civil servant with $16.4 \%, 13.8 \%$ and $11.7 \%$ respectively. Monthly disposal income concentrated on the 1000-3000RMB and 3001-5000RMB with 32.3\% and $34.6 \%$ respectively. The average time spent on online shopping for each time concentrated on within 1 hour and $1-2$ hours accounted $43.5 \%$ and $34.4 \%$ respectively. Based on the correlation results from Table 3, there is a significant correlation between company brand's reputation 
and customer trust (Pearson=0.463, p-value $=0.000$ ). Moreover, as the Pearson Correlation is more than 0.4, thus it can be concluded that the correlation between company brand's reputation and customer trust is moderate.

Additionally, there is a significant correlation between product quality and customer trust (Pearson $=0.663$, pvalue $=0.000$ ). Moreover, as the Pearson Correlation is more than 0.5 , thus result indicated that the correlation between product quality and customer trust is strong. There is also a significant correlation between after-sales service and customer trust level at $95 \%$ confidence interval (Pearson $=0.512$, $\mathrm{p}$-value $=0.000$ ). Moreover, as the Pearson Correlation is more than 0.5 , thus the correlation between after-sales service and customer trust is significantly strong.
Furthermore, there is a significant correlation between website quality and customer trust (Pearson $=0.502$, pvalue $=0.000$ ). Since the Pearson Correlation is more than 0.5 , thus it can be concluded that the correlation between website quality and customer trust is strong. Customer attitude towards risk and customer trust is also significant (Pearson=0.467, p-value $=0.000$ ). As such, all the five independent variables indicated a significant correlation with dependent variable that is customer trust.

Based on the multiple regression results above, the $\mathrm{p}$-value of every Hypotheses is lower than .05, which means the statistical results support $\mathrm{H} 1, \mathrm{H} 2, \mathrm{H} 3, \mathrm{H} 4$, and $\mathrm{H} 5$.

Table 2 Demographic of respondents

\begin{tabular}{|c|c|c|c|}
\hline Characteristic & Percentage $(\%)$ & Characteristic & Percentage (\%) \\
\hline Gender & & Education & \\
\hline Male & 34.1 & High school or less & 12.2 \\
\hline Female & 64.9 & Junior college & 19.5 \\
\hline Age & & Undergraduate & 46.1 \\
\hline $18-25$ & 19.8 & Master & 21.9 \\
\hline $26-30$ & 62.2 & PHD & 0.3 \\
\hline $31-40$ & 14.8 & Monthly disposable money & \\
\hline Above 40 & 3.1 & Under $1000 \mathrm{RMB}$ & 13.8 \\
\hline Occupation & & 1001-3000 RMB & 32.3 \\
\hline Student & 16.4 & 3001-5000RMB & 34.6 \\
\hline Company employee & 32.6 & 5001-10000RMB & 14.1 \\
\hline Civil servant & 11.7 & 10001-20000RMB & 4.4 \\
\hline Working in research institutes or teaching & 8.9 & Above 20000RMB & 0.8 \\
\hline Entrepreneur & 2.3 & $\begin{array}{l}\text { Average time spent shopping } \\
\text { online each time }\end{array}$ & \\
\hline Liberal professions & 13.8 & Within 1 hours & 43.5 \\
\hline Unemployed & 0.5 & 1-2hours & 34.4 \\
\hline \multirow[t]{2}{*}{ Others } & 13.8 & 2-3hours & 10.7 \\
\hline & & Above 3hours & 11.5 \\
\hline
\end{tabular}

Table 3 Customer trust on B2C e-commerce websites

\begin{tabular}{|c|c|c|c|c|c|c|c|}
\hline \multirow[b]{2}{*}{ Model (Hypothesis) } & \multicolumn{2}{|c|}{$\begin{array}{c}\text { Unstandardized } \\
\text { Coefficients }\end{array}$} & \multicolumn{2}{|c|}{$\begin{array}{c}\text { Standardized } \\
\text { Coefficients }\end{array}$} & \multicolumn{3}{|c|}{$95.0 \%$ Confidence Interval for $B$} \\
\hline & B & Std. Error & Beta & $\mathbf{t}$ & Sig. & $\begin{array}{l}\text { Lower } \\
\text { Bound }\end{array}$ & $\begin{array}{l}\text { Upper } \\
\text { Bound }\end{array}$ \\
\hline (Constant) & 0.774 & 0.149 & & 5.194 & 0.000 & 0.481 & 1.067 \\
\hline Company brand reputation & 0.110 & 0.044 & 0.119 & 2.522 & $0.012 * * *$ & 0.024 & 0.196 \\
\hline Product quality & 0.365 & 0.046 & 0.410 & 7.882 & $0.000 * * *$ & 0.274 & 0.456 \\
\hline After sales services & 0.095 & 0.040 & 0.117 & 2.368 & $0.018 * *$ & 0.016 & 0.173 \\
\hline Website quality & 0.131 & 0.047 & 0.137 & 2.813 & $0.005 * * *$ & 0.039 & 0.223 \\
\hline Customer attitude towards the risk & 0.080 & 0.036 & 0.103 & 2.220 & $0.027 * *$ & 0.009 & 0.151 \\
\hline $\mathrm{R}^{2}$ & 0.504 & & F-Test & & $76.686 * * *$ & & \\
\hline Adjusted $\mathrm{R}^{2}$ & 0.497 & & & & & & \\
\hline
\end{tabular}

***Significant at $0.01 * *$ Significant at 0.05

The standardized regression equation of the model of customer trust influencing factors can be summarized as: $\mathrm{Y}=0.774+0.11 \mathrm{X} 1+0.365 \mathrm{X} 2+0.095 \mathrm{X} 3+0.131 \mathrm{X} 4+0.08 \mathrm{X} 5$ Based on the results above, it is concluded that product quality has the highest influence on customer trust and followed by others such as website quality, company brand reputation, after-sales service. Customer attitude towards risk had the least influence on customer trust towards the B2C e-commerce in China. 
The reputation of the brand or company has a positive impact on the trust. If the online customers have no doubt on the reputation of the company, they will have confidence that the transaction with the online company. As similar result was found in the studies by Salo and Karjaluoto [29] and McKnight et al. [13] where a company's brand and reputation will have a positive and significant influence on the trust by customer. Internet is an effective medium of information transfer that spread information rapidly across time and space among Internet users. As such, online customers can view other people's perception on the reputation. In order to prevent discredit or poor judgment by others, company must emphasize on the evaluation by their existing online customers.

In order to fulfil their needs in daily life, consumers tend to purchase using online platform and conventional means of transactions. As such, it is rational to assume that the product quality is the most significant influencing factor in this study. The level of product quality directly determines whether the customer needs can be met or not, and the extent of meeting the expectation. This result concurs with past studies whereby the better quality of the product quality, the higher trust for B2C e-commerce [21][22].

The third hypothesis assumes that there is relationship between after-sales service and customer trust and results indicated that after-sales service are relevant in building trust. Usually, customers pay more attention to the aftersales service when they buy the electronic products [36]. By providing good after-sales service, this will guarantee trust from the consumers. It is also recommended that ecommerce business should provide the same maintenance service with the similar costs as the traditional trading. For instance, companies like JD.COM and Suning.com which sold electrical appliances in conventional and online platform allowed their customer to service their appliances in any physical service center. Such initiatives will enhance the customer trust toward B2C e-commerce business platform.

Website quality $(\beta=0.131)$ is another factor influence on customer trust and has a positive influence on customer trust. Lewicki, Mc Allister and Bies [37], and Co [38] also had the similar findings since website directly affects the customer experience about transaction process and reflect the technology of the company. This also reflected the company's management idea and management model in building trust among the customers.

The last hypothesis is also being supported in this study which concerns on the relationship between customer attitude towards risk and customer trust despite that some of the past empirical studies have shown that there is no relationship between customer attitude towards risk and customer trust [11][37]. Due to the virtual network environment, customers relied on their instinct and perception towards risk. This means that customers tend to choose trusted e-commerce company purchase based on their perception and instinct. Most customers fear that their personal information will be misused by unauthorized parties since identity and payment details are commonly used for online transactions. As such, detailed privacy policy posted on the website will be a good way to eliminate customer concerns and improve their perception towards buying risk.

\section{CONCLUSIONS}

The results revealed that company brand's reputation, product quality, after-sales service, website quality, customer attitude toward risk had significant relationships with customer trust. Among all the influencing factors, product quality is considered as the most relevant influencing factor and this is followed by website quality, company brand's reputation, after-sales service, customer attitude toward risk. At present, a large number of website operations in China pursues technical innovation and content innovation to attract customers. In addition, clickthrough rates, the accumulation of a large number of customer information together with price stategies are perceived to be the main source of value creation for most e-commerce business in China. This study provides knowledge for e-commerce practitioners to adopt a more effective marketing strategies to improve the customers trust combined. This study also showed that website practitioners should focus on products and services as only the product itself can truly meet the needs of the customers. Website should be thoroughly put aside "techno-enabled" and focus on the quality and efficient service management to instill customer trust. For website operators, establishing a long-term relationship with customers can create higher customer lifetime value for customers who preferred ecommerce.

\section{REFERENCES}

[1] B.T. Luo, The China's electric business report. (2016) Available from: <http://finance.china.com.cn/ roll/20160630/3792176.shtml>. [18 January 2021].

[2] The 2015 China Internet security report. Available from: $\quad<$ http://zt.360.cn/1101061855.php?dtid= $1101062370 \& \operatorname{did}=1101654296>$. [2 January 2021].

[3] R.G. Wei, The analysis of the network shopping's reason. 2016. Available from: <http://www.xzbu.com/2/ view-417790.htm>. [2 January 2021].

[4] B. Barber, The logic and limits of trust. Journal of Computer Mediated Communication. 5 (2) (1983), 1-20.

[5] N. Luhmann, Trust and power. Journal of Computer Mediated Communication. 5 (2) (1979), 1-20.

[6] L.G. Zucker, Production of trust: institutional sources of economic structures. Journal of Research in Organizational Behavior. 8 (5) (1986), 53-111.

[7] D. Gambetta, Making and breaking cooperative relations. Journal of Basit Blackwell. 34 (5) (1988), 213237. 
[8] J.D. Lewis. Trusted partners: How companies build mutual, trust and win together. Free Press. 2007

[9] C.L. Corritore, B. Kracher, S. Wiedenbeck, Online trust: concept, evolving themes, a model. Journal of Human-Computer Studies. 58 (18) (2003), 737-758. DOI: https://doi.org/10.1016/S1071-5819(03)00041-7

[10] W. Aslam, A, Hussain, K. Farhat, I. Arif, Underlying factors affecting the customer trust and loyalty in the e-commerce. Business Perspective and Research. 8 (2) (2019), 297-323. DOI: https://doi.org/ $10.1177 \% 2$ F2278533719887451

[11] M. Koufaris, E. Hamption-Sosa, The development of initial trust in an online company by new customer. Journal of Information and Management. 41(3) (2004), 377-397. DOI: https://doi.org/10.1016/j.im.2003.08.004

[12] D.L. Hoffman, T.P. Novak, M. Peralta, Building consumer trust online. Journal of Communications of the ACM. 42 (4) (1999), 80-85. DOI: https://doi.org/ 10. $1145 / 299157.299175$

[13] D. McKnight, V. Choudhury, C. Kacmar, The impact of initial consumer trust on intentions to transact with a website: A trust building mode. Journal of Strategic Information System. 11 (20) (2002), 297-323. DOI: https://doi.org/10.1016/S0963-8687(02)00020-3

[14] K.D. Ruyter, M. Wetzels, M.H.P. Kleijnen, Customer adoption of e-services an experimental study. Journal of Service Industry Management. 12 (2) (2001), 184-207. DOI: https://doi.org/10.1108/ 09564230110387542

[15] K.K. Kim, B. Prabhakar, Initial trust and the adoption of $\mathrm{B}$ to $\mathrm{C}$ e-commerce: the case of internet banking. ACM SIGMIS Database: the DATABASE for Advances in Information Systems. 35(2) (2004). DOI: https://doi.org/10.1145/1007965.1007970

[16] M.K.O.Lee, E. Turban, A trust model for consumer internet shopping. Journal of Electronic Commerce. 6(1) (2012), 75-91. https://www.jstor.org/stable/27751003

[17] M. A. Shareef, A. Baabdullah, S. Dutta, V. Kumar, Y. K. Dwivedi, Consumer adoption of mobile banking services: An empirical examination of factors according to adoption stages. Journal of Retailing and Consumer Services. 43 (2018), 54-67. DOI: https://doi.org/10. 1016/j.jretconser.2018.03.003

[18] P.K. Zhang, X.F. Zhang, Customer trust evaluation model research in e-commerce market. Journal of China's Circulation Economy. 4 (2) (2006), 35-38.
[19] J. H. Yu, Online trust evaluation model and its factors. Journal of Software Tribune. 20 (9) (2007), 3638 .

[20] H. W. Wang, Y. Q. Xia, The strategy research about initial trust in B to $\mathrm{C}$ e-commerce. Journal of Shandong Normal University. 23 (4) (2008), 107-108.

[21] J. Zhang, E. Mao, Understanding the acceptance of mobile SMS advertising among young Chinese consumers. Psychology \& Marketing. 25(8) (2008), 787805. DOI: https://doi.org/10.1002/mar.20239

[22] C. M. Cheung, M. K. Lee, Trust in Internet shopping: Instrument Development and Validation through Classical and Modern Approaches. Journal of Global Information Management. 9 (3) (2001), 23-27. DOI: https//doi.org/10.4018/jgim.2001070103

[23] F. B. Tan, P. Sutherland, Online consumer trust: a multi-dimensional model. Journal of Electronic Commerce in Organizations, 2 (3) (2002), 40-58. DOI: http://doi.org/10.4018/jeco.2004070103

[24] D, Gefen, Customer loyalty in e-commerce. Journal of Association for Information Systems. 3 (1) (2002), 27 51. DOI: https://doi.org/10.17705/1jais.00022

[25] D. Gefen, E. Karahanna, D.W.Straub, Trust and TAM in online shopping: An integrated model. Journal of MIS Quarterly. 27 (1) (2003), 51-90. DOI: https://doi.org/10.2307/30036519

[26] H. W. Kim, Y. Xu, J. Koh, A comparison of online trust building factors between potential customers and repeat customers. Journal of the Association for Information Systems. 5 (10) (2004), 392-420. DOI: https://doi.org/10.17705/1jais.00056

[27] H. T. Tsai, H. C. Huang, Y.L. Jaw, W.K. Chen, Why on-line customers remain with a particular e-retailer: An integrative model and empirical evidence. Journal of Psychology and Marketing. 23 (5) (2010), 447-464. DOI: https://doi.org/10.1002/mar.20121

[28] J. Benamati, M. A. Serva, Trust and distrust in online banking: their role in developing countries. Journal of Information Technology for Development. 13 (2) (2011), 161-175. DOI: https://doi.org/10.1002/itdj. 20059

[29] J, Salo, H. Karjaluoto, A conceptual model of trust in the online environment. Journal of Online Information Review 31(5) (2010), 604-621. DOI: https://doi/org/ $10.1108 / 14684520710832324$ 
[30] D. Gefen, E-commerce: the role of familiarity and trust. Omega. 28 (6) (2000), 725-737. DOI: https: doi.org/10.1016/S0305-0483(00)00021-9

[31] J. W. Creswell, Research design: quantitative and qualitative approaches, Sage, Thousand Oaks, 1994.

[32] R. V. Krejcie, D.W. Morgan, Determining sample size for research activities. Journal of Educational and Psychological Measurement. 30 (3) (1970), 607-610. DOI: https://doi.org/10.1177\%2F001316447003000308

[33] S. A. Krishnan, R. Aron, Group buying on the web: A comparison of price-discovery mechanisms. Journal of Management Science. 11 (5) (2008), 1546-1562. DOI: https://doi.org/10.1287/mnsc.49.11.1546.20582

[34] U. Sekaran, Research Methods for Business: A Skill-Building Approach. 4th Edition, John Wiley \& Sons, New York, 2003.

[35] J. M. Cortina, What is coefficient alpha? An examination of theory and applications. Journal of Applied Psychology. 3 (78) (1993), 98-104. DOI: https://psycnet.apa.org/doi/10.1037/0021-9010.78.1.98

[36] Y. Liu, Y. Yi, L. Tao, Y. Wang, Relationship stability, trust and relational risk in marketing channels: Evidence from China. Industrial Marketing Management. 37(4) (2008), 432-446. DOI: https:// doi.org/10.1016/j.indmarman.2007.04.001

[37] R. J. Lewicki, D. J. McAllister, R.J. Bies, Trust and distrust: new relationships and realities. Journal of Academy of Management Review. 23 (3) (1998), 438458. DOI: https://doi.org/10.2307/259288

[38] E. Co, The mechanism of trust and distrust formation and their relational outcomes. Journal of Retailing, 82 (1) (2006), 25-35. DOI: https://doi. org.10.1016/j.jretai.2005.11.002 